GRASAS Y ACEITES 68 (2)

April-June 2017, e196

ISSN-L: 0017-3495

doi: http://dx.doi.org/10.3989/gya.1271162

\title{
Preparation of stable tea seed oil nano-particle emulsions by a low energy method with non-ionic surfactants
}

\author{
M. Kanlayavattanakul ${ }^{\mathrm{a}, \mathrm{b}, \varpi}$ and N. Lourith ${ }^{\mathrm{a}, \mathrm{b}}$ \\ ${ }^{a}$ School of Cosmetic Science, Mae Fah Luang University, Chiang Rai 57100, Thailand. \\ ${ }^{b}$ Phytocosmetics and Cosmeceuticals Research Group, Mae Fah Luang University, Chiang Rai 57100, Thailand. \\ ${ }^{\square}$ Corresponding author: mayuree@mfu.ac.th
}

Submitted: 03 December 2016; Accepted: 06 March 2017

SUMMARY: Tea seed oil nano-particle emulsions were prepared. Non-ionic surfactants containing Tween 80 and Span $80(1: 1, w / w)$ were mixed with propanol (3-9:1, w/w) to give $S_{\text {mix }}$, which was thereafter mixed with tea seed oil. The mixture was titrated with water at $150 \mathrm{rpm}$ to give clear or bluish and bluish-white emulsions. Twelve nano-particle emulsions with 64.64 to $72.73 \% \mathrm{~S}_{\text {mix }}, 16.66$ to $27.27 \%$ oil and 9.09 to $16.67 \%$ water with particle sizes between 207.00 to $430.10 \mathrm{~nm}$, PDI of 0 to 0.4 , $\zeta$-potential of -42.00 to $-49.63 \mathrm{mV}$, pH of 7.04 to 7.32 and 151.33 to $241.93 \mathrm{cps}$, were stable following an accelerated stability test and long term storage at room temperature and 4 and $45^{\circ} \mathrm{C}$ for 90 days, although one system $\left(16.66 \%\right.$ oil and $\left.66.67 \% \mathrm{~S}_{\text {mix }}\right)$ was separated. This nano-particle emulsion formulation is concise and feasible for an industrial development of topical products containing tea seed oil.

KEYWORDS: Camellia oleifera; Emulsion; Formulation; Self-emulsifying; Stability; Tea seed oil

RESUMEN: Preparación de emulsiones estables de nanopartículas de aceite de semilla de té mediante un método de baja energía con tensioactivos no iónicos. Se prepararon emulsiones de nanopartículas de aceite de semilla de té. Se mezclaron tensioactivos no iónicos que contenían Tween 80 y Span 80 (1:1, p/p) con propanol (3-9: 1, p/p) para dar $\mathrm{S}_{\text {mix }}$ que después se mezcló con aceite de semilla de té. La mezcla se valoró con agua a 150 rpm para dar emulsiones claras o azuladas y blanco azulado. Doce emulsiones de nanopartículas con 64,64 a 72,73\% de $S_{\text {mix }}$, 16,66 a $27,27 \%$ de aceite y 9,09 a $16,67 \%$ de agua con tamaños de partícula entre 207,00 y 430,10 nm, PDI de 0 a 0,4 , potencial $\zeta$ de $-42,00$ a $-49,63 \mathrm{mV}$, $\mathrm{PH}$ de 7,04 a 7,32 y 151,33 a 241,93 cps, se mantuvieron estables tras el ensayo de estabilidad acelerada y almacenamiento a largo plazo a temperatura ambiente y 4 y $45^{\circ} \mathrm{C}$ durante 90 días, aunque uno de los sistemas (16,66\% de aceite y 66,67\% de $\mathrm{S}_{\text {mix }}$ ) se desvió. Esta formulación de emulsión de nanopartículas es concisa y factible para un desarrollo industrial de productos tópicos que contienen aceite de semilla de té.

PALABRAS CLAVE: Aceite de semilla de té; Auto-emulsionante; Camellia oleifera; Emulsión; Estabilidad; Formulación

ORCID ID: Kanlayavattanakul M http://orcid.org/0000-0001-7741-8235, Lourith N http://orcid.org/0000-0003$0452-4517$

Citation/Cómo citar este artículo: Kanlayavattanakul M, Lourith N. 2017. Preparation of stable tea seed oil nanoparticle emulsions by a low energy method with non-ionic surfactants. Grasas Aceites 68 (2), e196. http://dx.doi. org/10.3989/gya.1271162

Copyright: (C) 2017 CSIC. This is an open-access article distributed under the terms of the Creative Commons Attribution (CC-by) Spain 3.0 License. 


\section{INTRODUCTION}

Tea seed oil extracted from the seed of Camellia oleifera Abel. is used extensively in Asian cuisine and personal care products (Su et al., 2014) This vegetable oil has several therapeutic effects and is used for stomachache and abdominal pain due to its inhibiting activity against gastrointestinal mucosal injury (Cheng et al., 2014). In addition, the oil has been topically applied to treat skin burn and is able to reduce blood lipids. Moreover, it possesses a remarkable antioxidant activity (Lee and Yen, 2006) with a hepato-protecting activity (Lee et al., 2007) including inhibition against lung metastasis of melanomas (Miura et al., 2007).

This edible oil has health benefits comparable to olive oil and better than sunflower oil (Sahari et al., 2004) due to its bioactive fatty acid constituents, palmitic, linoleic, oleic and stearic acids, which are important in cosmetics and used for skin, hair and nail nourishing, inflammation, dandruff and hair loss treatments with the ability to enhance hair growth. These fatty acids exhibit skin and nail hydrating effects and suppress sebum secretion at the same time. Therefore, bio-oils with these bioactive fatty acids are used in acne care products (Kanlayavattanakul and Lourith, 2011).

Topical application of the oil, however, leaves a greasy feeling on the skin. In addition, the bioavailability of the poorly water-soluble active ingredient is limited (Shafiq et al., 2007; Zhao et al., 2010). A nanometer range emulsion based delivery system enhances the applicability and prolongs activity and therefore has received great attention recently $(\mathrm{Li}$ et al., 2012).

Nano-size emulsions are transparent or bluish and disperse colloids with a typical particle size of 10 to $500 \mathrm{~nm}$ (Polychniatou and Tzia, 2014). They have gained much attention in food and health promotion products including cosmetics (Saraf, 2010), but particularly those of edible oil containing nonionic surfactants (Li et al., 2012; Polychniatou and Tzia, 2014). Micro-emulsions and nano-emulsions are the most widely used terms for nano-particle emulsions which differ in stability and formulation methods (McClements, 2012).

Micro-emulsions are formed by mixing oil, surfactants and water with low-energy. The colloidal dispersing system with lower free energy than that of the separate phases spontaneously generates nano-particles. Accordingly, micro-emulsions are theoretically thermodynamically stable. Phase inversion or self-emulsifying methods are also known as the method of micro-emulsion (McClements, 2012). On the contrary, nano-emulsions are kinetically stable and are prepared with high-energy methods by high-shear stirrers, high pressure homogenizers and ultrasound generators (Lourith et al., 2016; McClements, 2012; Solans and Solé, 2012).
Although self-emulsifying emulsion using low energy entails lower preparation costs, it has rarely been reported (Lourith et al., 2016; Solans and Solé, 2012). Therefore, the preparation of self-emulsifying nano-emulsion using non-ionic surfactants and tea seed oil is proposed in order to produce appropriate applications in innovative products which are suitable for industrial purposes.

\section{MATERIALS AND METHODS}

\subsection{Preparation of self-emulsifying nano-particle emulsion}

Nano-particle emulsions were spontaneously prepared using the aqueous titration method (Shafiq et al., 2007; Zhao et al., 2010). The mixture of food grade Tween 80 and Span 80 (Nof, Japan) $(1: 1, \mathrm{w} / \mathrm{w})$ was mixed with the co-surfactant, propanol (Abbsasi and Radi, 2016), which was purchased from QReC (New Zealand) in different proportions $(1-9: 1, \mathrm{w} / \mathrm{w})$. The resulting mixture was labeled as $S_{\text {mix }}$. The ratio of tea seed oil (Forecus, Thailand) and $\mathrm{S}_{\text {mix }}$ was thereafter thoroughly mixed in different proportions from 1-9: 9-1. The mixture of oil and $\mathbf{S}_{\text {mix }}$ was thereafter mixed with water and visually graded into five categories, A-E (Lourith et al., 2016; Shafiq et al., 2007):
A: Rapidly forming nano-emulsion (within 1 min) with a clear or bluish appearance
B: Rapidly forming, slightly less clear emul- sion with a bluish-white appearance
C: Fine milky emulsion forming within $2 \mathrm{~min}$
D: Dull, grayish-white emulsion having a slightly oily appearance taking longer than 2 min to emulsify
E: Poor or minimal emulsification with large oil globules on the surface

Hydrophilic-lipophilic balance (HLB) of the prepared emulsions was calculated according to the surfactant components, as shown below:

$\mathrm{HLB}=f_{\mathrm{T}} \mathrm{HLB}_{\mathrm{T}}+f_{\mathrm{S}} \mathrm{HLB}_{\mathrm{S}}$

where $\mathrm{HLB}_{\mathrm{T}}$ and $\mathrm{HLB}_{\mathrm{S}}$ are $\mathrm{HLB}$ values, and $f_{\mathrm{T}}$ and $f_{\mathrm{S}}$ are the weight fractions of Tween 80 and Span 80, respectively (Wang et al., 2009).

\subsection{Physicochemical and stability evaluations}

The emulsions of A grade were stored under ambient conditions for 3 days in order to allow a complete transport processes of the emulsion until its equilibrium was reached (McClements, 2012). Emulsions whose texture remained homogeneous with a clear appearance represent A grade 
were scaled up for physicochemical characterization and the accelerated stability test by means of heating and cooling for 7 cycles $\left(45\right.$ and $4{ }^{\circ} \mathrm{C}$, each $24 \mathrm{~h}$ ). The droplet size, polydispersity index (PDI) and $\zeta$-potential were determined using the dynamic light scattering and micro-electrophoresis device (Nano-ZS90, Malvern Instruments, UK) with a $50 \mathrm{mV}$ laser. The samples were dispersed in de-ionized water $(0.2 \%)$. The measurement time was 2 min and each run underwent 12 subruns, performed at a fixed angle of $90^{\circ}$ with a sensitivity range between $10 \mathrm{~nm}$ to $5 \mathrm{~m}$ at room temperature. The stable emulsions were thereafter scaled up and stability was evaluated under 4, 25 and $45^{\circ} \mathrm{C}$, separately, for 3 months. Droplet size, PDI and $\zeta$-potential were determined as usual in addition to $\mathrm{pH}$ (Mettler Toledo, s20, Switzerland) and viscosity $\left(25^{\circ} \mathrm{C}, 160 \mathrm{rpm}\right.$, spindle no. 2; Brookfield, RVDV2T extra, USA). All of the measurements were done in triplicate (Shafiq et al., 2007).

\section{RESULTS AND DISCUSSION}

\subsection{Formulation of tea seed oil nano-particle emulsions with non-ionic surfactants}

HLB is the important criteria for an emulsion formation, particularly for spontaneous phase transitions that are driven by thermodynamic effects at a constant temperature with minimal energy consumption. Tween $80($ HLB $=15)$ and Span $80($ HLB $=4.3)$ were therefore chosen in a combination of non-ionic surfactants (Polychniatou and Tzia, 2014). Polyols and short chain alcohols were trial used as co-surfactants due to the similarity of these solvents to water in terms of their hydrogen bond formation and high dielectric constants. In addition, they are immiscible in apolar solvents with higher critical micelle concentrations in polar non-aqueous solvents than water, resulting in penetration into the surfactant interface which self-assemble in alcohols (Garti et al., 2001), thus reducing interfacial tensions accordingly (Rao and MacClements, 2012). However, those of propylene glycol and polyethylene glycol afforded none of the A grade emulsions. Therefore, propanol and ethanol were further designed as the co-surfactants. A visual grading using propanol as the co-surfactant resulted in $28 \mathrm{~A}$ grade, $33 \mathrm{~B}$ grade, $233 \mathrm{C}$ grade and $516 \mathrm{D}$ grade emulsions (Figure 1a). Those of the A grade were included for short-term stability (McClements, 2012) and resulted in 12 systems (P1-P12) that retained their original macroscopic appearance which thereafter were determined as nano-particle emulsions $(242-426 \mathrm{~nm})$ as shown in Figure 1b, with PDI of 0.1 to 0.4 indicating the narrow size distribution. Although a non-ionic surfactant system is used in this preparation of nano-particles, the emulsions that should be ruled by the free fatty acids of tea seed oil with anionic nature had a negative charge (Li et al., 2012). The observed absolute $\zeta$-potentials greater than $40 \mathrm{mV}$ guide the stability of the formed emulsion with a high energy barrier, protecting coalescence of the internal oil phase (Zhao et al., 2010). The A grade emulsions with the greatest tea seed oil content of $27.27 \%$ (P7, 9 and 12$)$ were shown to have a higher mean droplet diameter $(414.53 \pm 31.80,426.03 \pm$ 15.19 and $387.47 \pm 17.05 \mathrm{~nm}$ ). The systems with the lower proportions of surfactants and co-surfactant, resulting in a lesser degree of surfactant self-assembly weakly minimized the liquid crystal phase regions (Garti et al., 2001) including a low transportation rate of oil across the water phase (McClements, 2012). The droplet size tends to be bigger accordingly. $\mathrm{pH}$ and viscosity (Figure $2 \mathrm{~b}$ ) of the clear emulsions were in the same range of the vegetable oil's nano-particle emulsion containing non-ionic surfactants (7.04 to 7.32 and 151 to $242 \mathrm{cps}$ ) that are commercially produced (Odile et al., 2001; Quemin, 2001). Although ethanol gave A grade emulsions, they were highly viscous (data not shown) and were excluded from this study.

Propanol influences the two-phase area by improving the solubilization capacity of the interface, which is in contrast to a longer chain alcohol (Garti et al., 2001). The HLB of the surfactants was designed at the range of $8-16$ for a higher possibility of o/w emulsion preparation (Roohinejad et al., 2015). HLB regulates the adsorption of surfactants to $\mathrm{o} / \mathrm{w}$ interfaces by differentiating the particle size accordingly. An interfacial film is formed and the interfacial tensions are decreased with high HLB. These phenomena facilitate droplet disruption, thereby promoting small droplets and improving long-term stability (Rao and McClements, 2012). The propanolic $\mathrm{S}_{\text {mix }}$ system (64.64 to $81.82 \%$ ) with HLB between 9.22 to 9.41 yielded tea seed oil nanoparticle emulsions with 9.09 to $16.67 \%$ water. The proportion of surfactant that was higher than $50 \%$ was in harmony in the used range for the formation of a stable self-emulsifying delivery system (Tang et al., 2008).

\subsection{Stability of tea seed oil nano-particle emulsions}

Although the prepared tea seed oil nano-sized emulsions were prepared by means of microemulsion, a theoretically thermodynamically stable nano-particle, the stability of the emulsions was assessed to observe the phase behavior which is crucial for an industrial development because the micro-emulsion may be changed due to chemical degradation or microbial contamination (McClements, 2012). The prepared micro-emulsions presented in this context added 
(a)

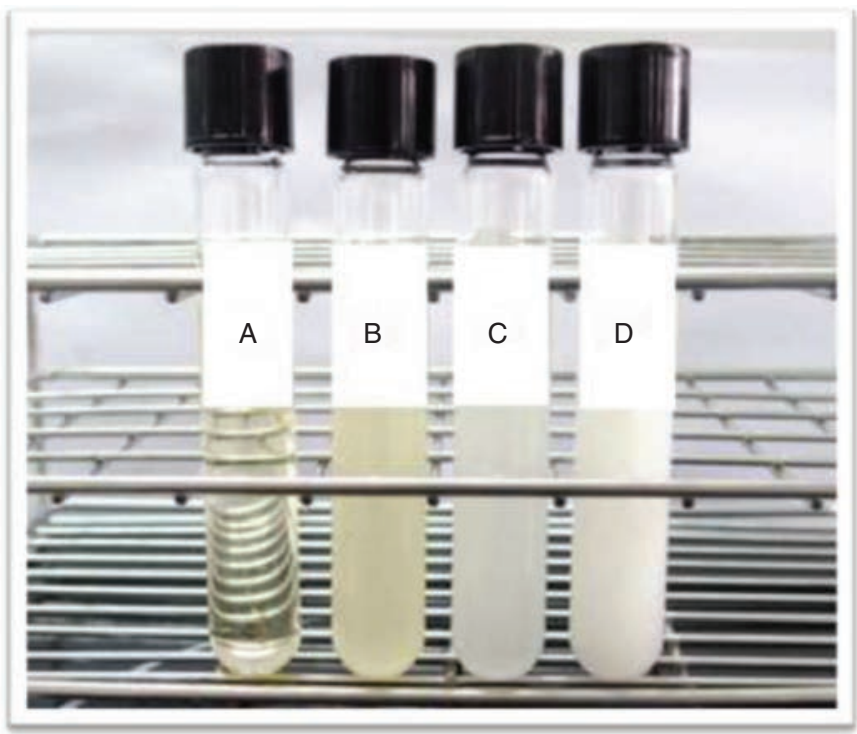

(b)

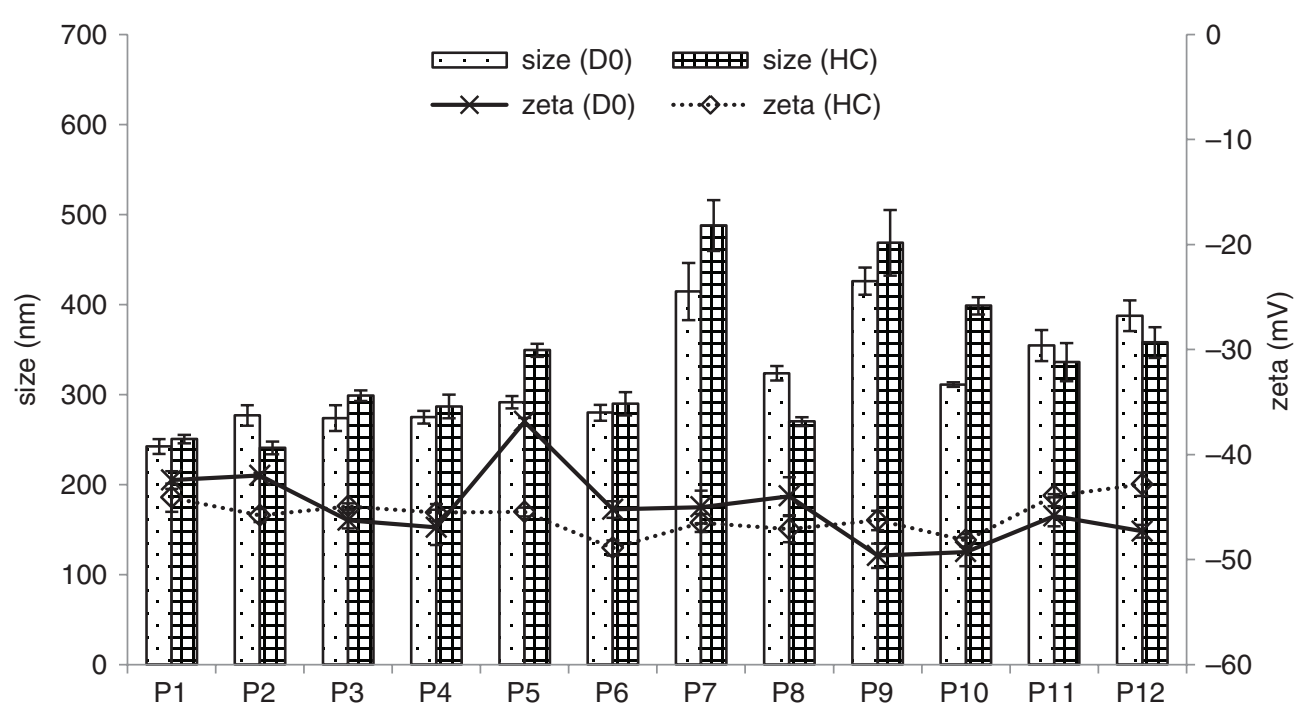

FIGURE 1. Visual grading of emulsion (a) and diameter and $\zeta$-potential of the freshly prepared tea seed oil nanoparticle emulsions (D0) and following accelerated stability test (HC) (b).

no preservatives. Accelerated stability tests were first conducted by using 7 heating and cooling cycles (Shafiq et al., 2007). The prepared tea seed oil micro-emulsions were stable with no phase separation, creaming or sedimentation. All of the prepared emulsions maintained their nanoparticle characteristics with a smaller droplet size than $500 \mathrm{~nm}$ as shown in Figure 1b with low PDI $(<0.4)$ indicating they were mono-dispersed. The stability in terms of $\zeta$-potential was in agreement. This electrostatic repulsion prevents flocculation, thus limiting sedimentation. This $\mathrm{S}_{\operatorname{mix}}$ was less affected by $\zeta$-potential. Although Ostwald ripening was noticed in some systems (P2, 8, 11, 12 ), the rest would be regulated by the ripening propagating coalescence as the diameters were larger.

Thereafter, long term stability of the prepared micro-emulsion was evaluated as shown in Figures 2 to 4 . Following 3 months of storage, the emulsions' diameters were less than $500 \mathrm{~nm}$. ' -potential remained negative with an absolute value greater than $40 \mathrm{mV}$, which suggests stability against coalescence. However, flocculation was noticed and further coalescence in the course of stability assessment was noted at day 30 of the observation, and 
Preparation of stable tea seed oil nano-particle emulsions by a low energy method with non-ionic surfactants $\bullet 5$

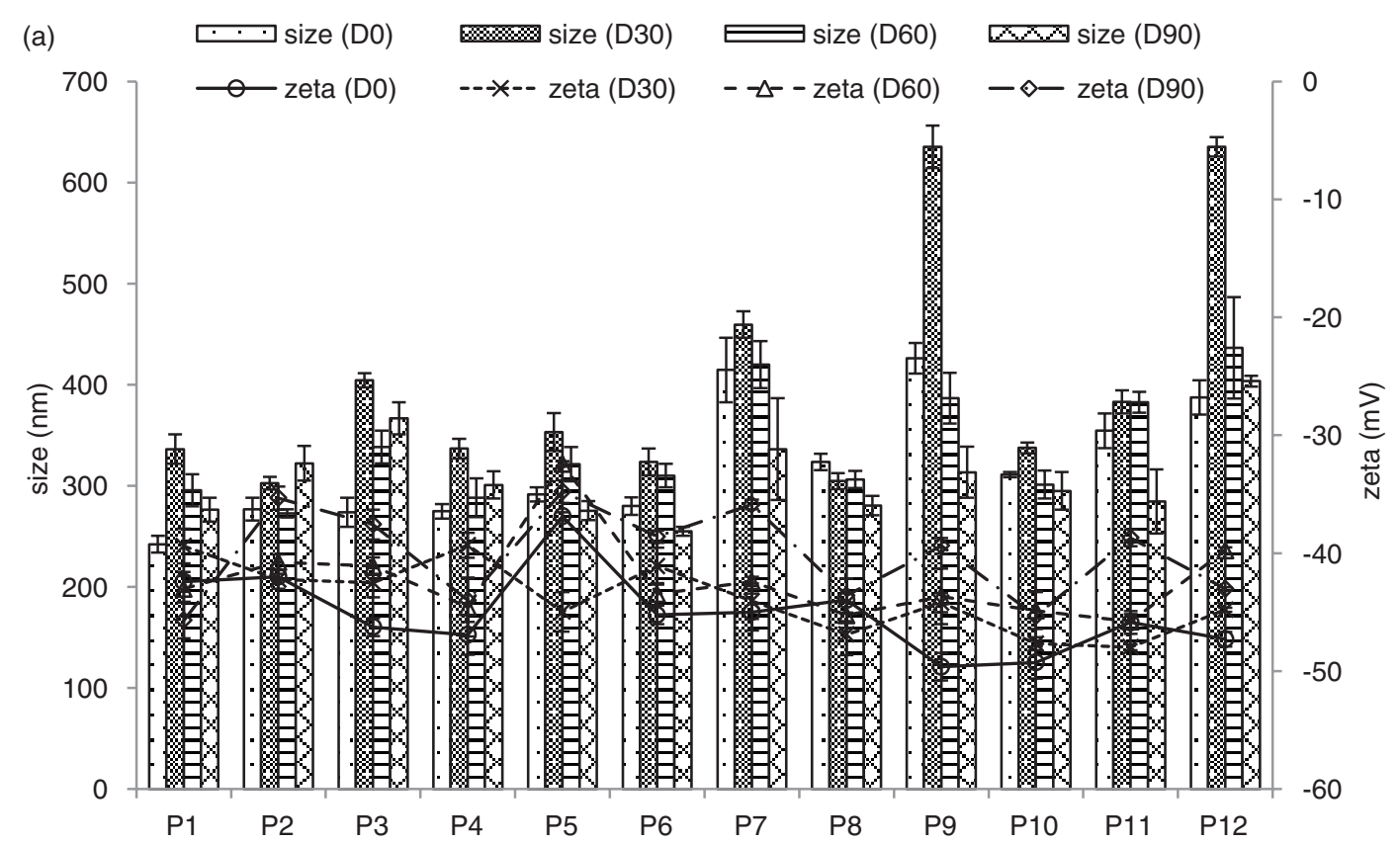

(b) $\square$ viscosity (D0) viscosity (D30)
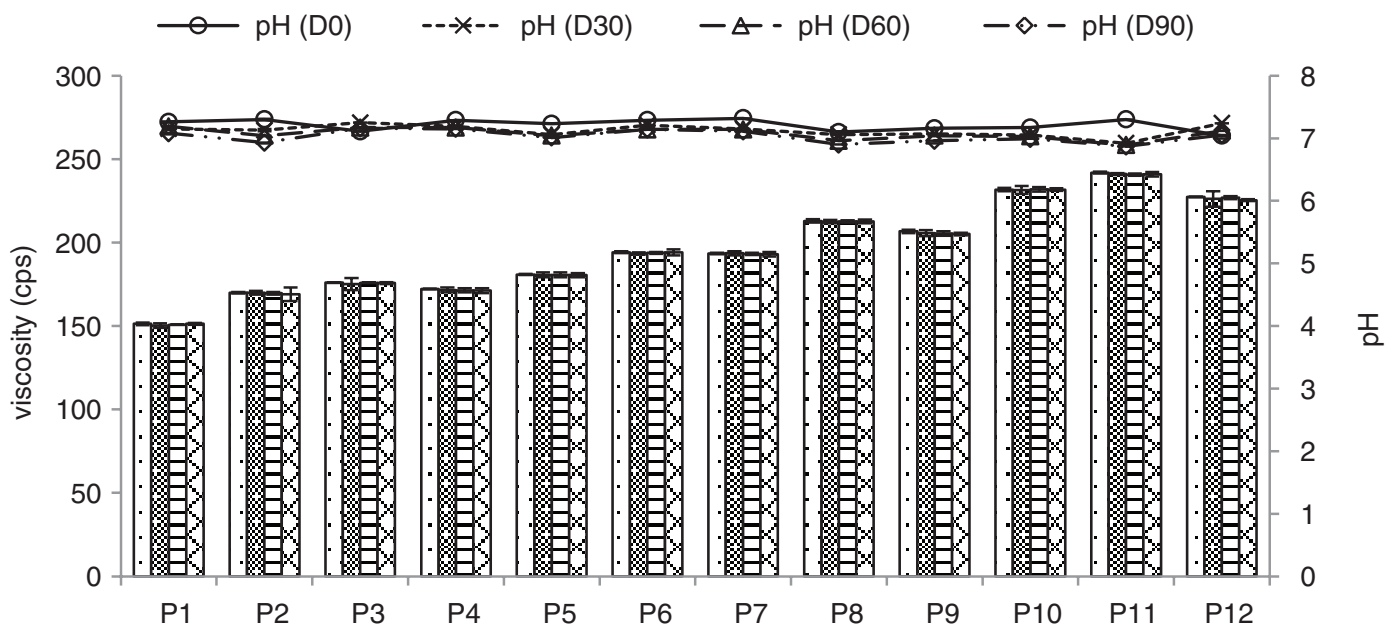

FIGURE 2. Diameter and $\zeta$-potential (a) and $\mathrm{pH}$ and viscosity (b) of tea seed oil nanoparticle emulsions under room temperature storage for 3 months.

thereafter ripped into a smaller size, although at a different time interval and at a different temperature. $45^{\circ} \mathrm{C}$ was shown to be the most affective followed by ambient condition and $4^{\circ} \mathrm{C}$. However, P11 stored at $4{ }^{\circ} \mathrm{C}$ was dramatically changed and phases were separated following day 60 of the study. This system was discontinued for stability studied at $4{ }^{\circ} \mathrm{C}$.

$\mathrm{pH}$ and viscosity remained in the same range, although there were some shifts. The acidified nanoparticle emulsions were affected, possibly due to the deterioration of fatty acids and other organic substances in the oil as no preservatives were added. A greater viscosity following storage is possible in nano-particle emulsions produced by non-ionic surfactant systems (Nazarzadeh et al., 2013). The twophase area is supposed to be shrunk with a short chain alcohol that is used as a co-surfactant (Garti et al., 2001) and plays a role in the viscosity accordingly, although this was only slightly observed in this system. 


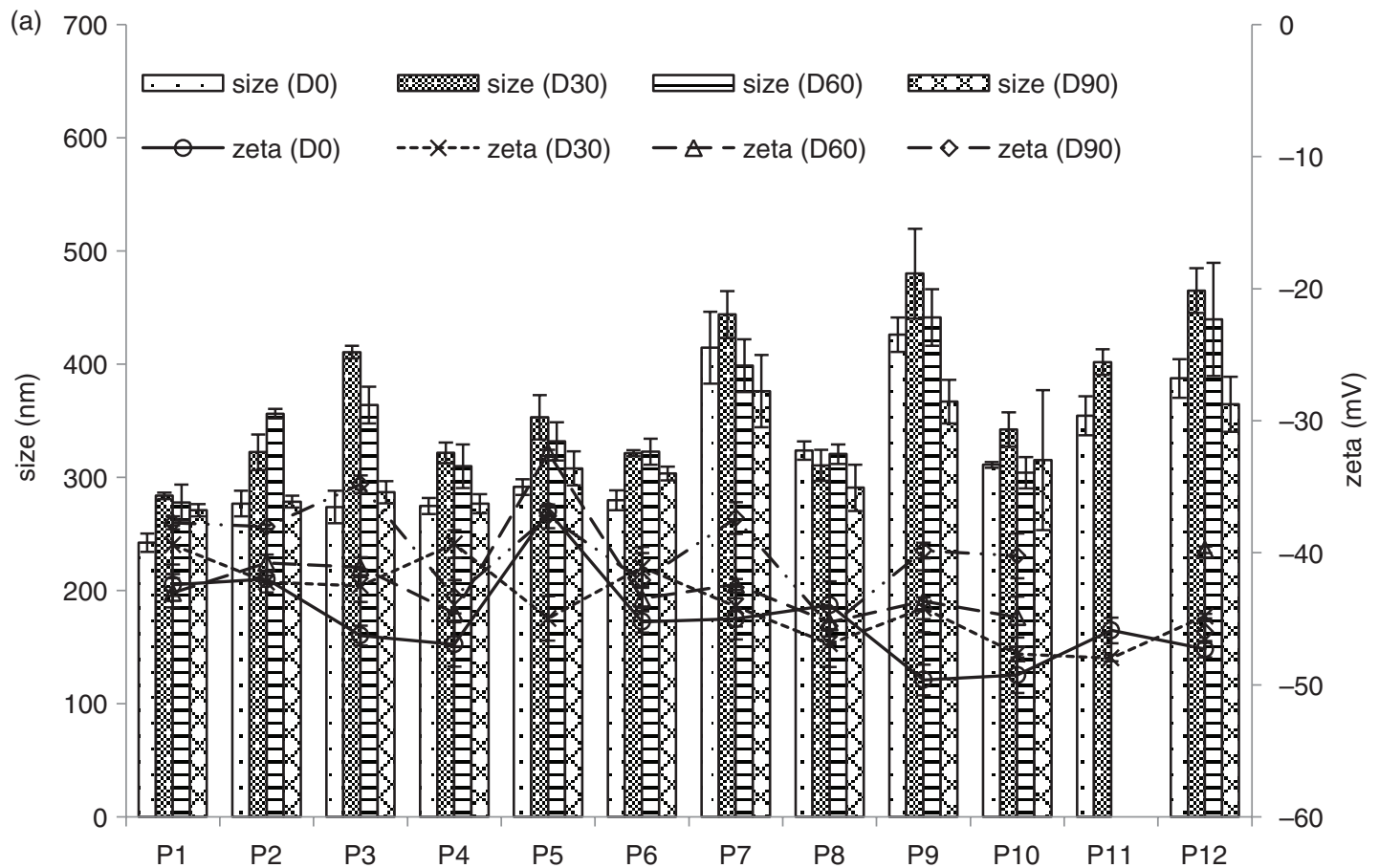

(b)


FIgURE 3. Diameter and $\zeta$-potential (a) and $\mathrm{pH}$ and viscosity (b) of tea seed oil nanoparticle emulsions under $4{ }^{\circ} \mathrm{C}$ storage for 3 months. 

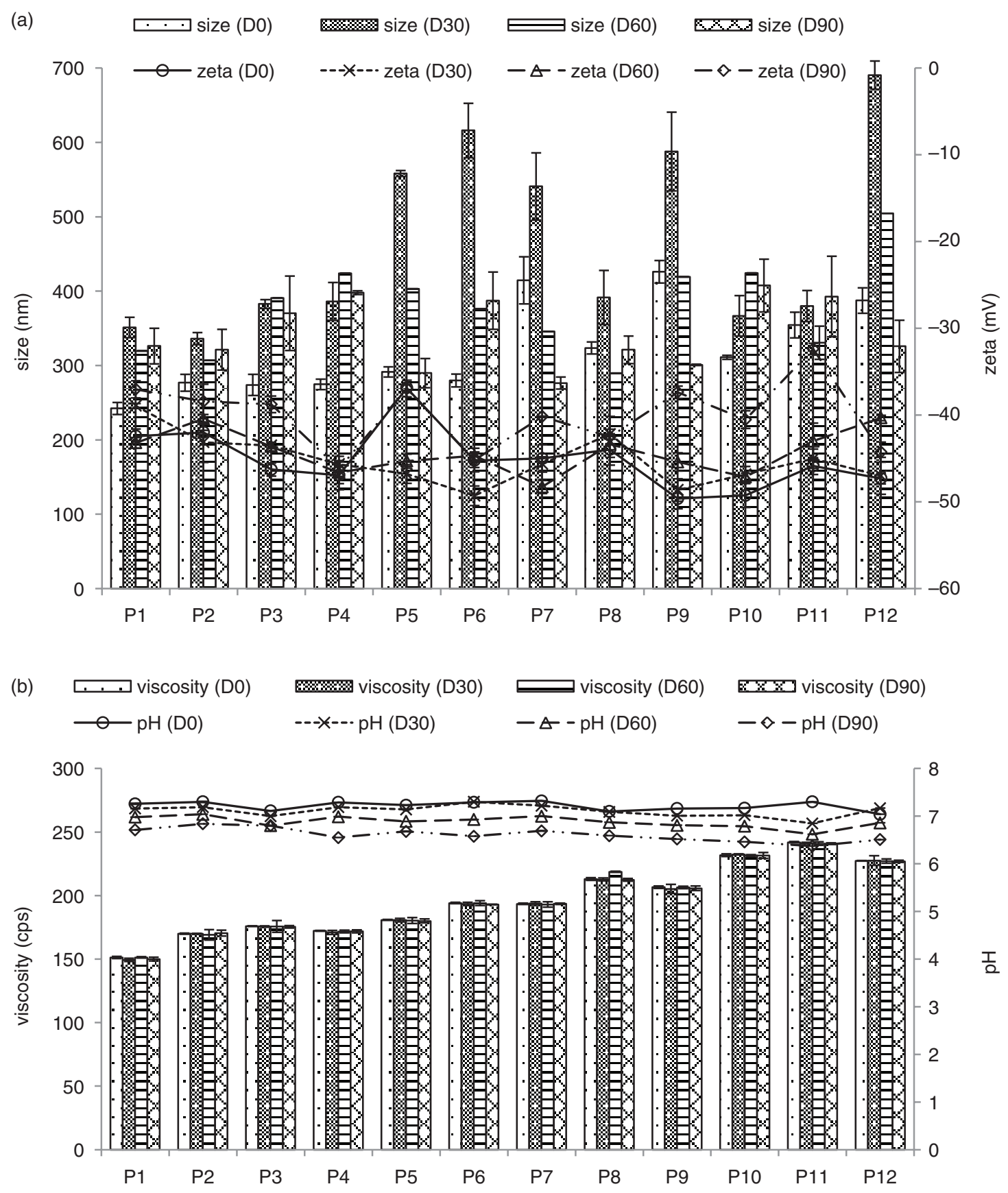

FIgURE 4. Diameter and $\zeta$-potential (a) and $\mathrm{pH}$ and viscosity (b) of tea seed oil nanoparticle emulsions under $45^{\circ} \mathrm{C}$ storage for 3 months.

\section{CONCLUSIONS}

Self-emulsifying nano-particle emulsions containing tea seed oil could be prepared by a practical method. Tea seed oil micro-emulsions with good viscosity and $\mathrm{pH}$ suitable for topical products were stable. The developed tea seed oil nano-particle emulsions are suggested to be stored at $4{ }^{\circ} \mathrm{C}$ or ambient temperature. The safety of these tea seed oil nano-particle emulsions should be challenged prior to their efficacy evaluation including sensory assessment. Preparations of micro-emulsion of the natural bioactive oils are encouraged. The innovative delivery system with a prolonged activity of the poorly-water soluble actives will widen the availability of various applications such as cosmetic and nutraceutical products with a feasible practice for industrial preparations. 


\section{ACKNOWLEDGMENTS}

This research was financially supported by Mae Fah Luang University (fiscal year 2015 grant no. 58108050016).

\section{REFERENCES}

Abbsasi S, Radi M. 2016. Food grade microemulsion systems: canolaoil/lecithin:n-propanol/water. Food Chem. 194, 972979. https://doi.org/10.1016/j.foodchem.2015.08.078

Cheng Y-T, Wu S-L, Ho C-Y, Huang S-M, Cheng C-L, Yen G-C. 2014. Beneficial effects of Camellia oil (Camellia oleifera Abel.) on letoprofen-induced gastrointestinal mucosal damage through upregulation of HO-1 and VEGF. J. Agric. Food Chem. 62, 642-650. http://dx.doi.org/10.1021/jf404614k

Garti N, Yaghmur A, Leser ME, Clement V, Watzke HJ. 2001. Improved oil solubilization in oil/water food grade microemulsions in the presence of polyols and ethanol. J. Agric. Food Chem. 49, 2552-2562. http://dx.doi.org/10.1021/jf001390b

Kanlayavattanakul M, Lourith N. 2011. Therapeutic agents and herbs in topical application for acne treatment. Int. J. Cosmet. Sci. 33, 289-297. http://dx.doi. org/10.1111/j.1468-2494.2011.00647.x

Lee C-P, Yen G-C. 2006. Antioxidant activity and bioactive compounds of tea seed (Camellia oleifera Abel.) oil. J. Agric. Food Chem. 54, 779-784. http://dx.doi.org/10.1021/jf052325a

Lee C-P, Shih P-H, Hsu C-L, Yen G-C. 2007. Hepatoprotection of tea seed oil (Camellia oleifera Abel.) against CCl4induced oxidative damage in rats. Food Chem. Toxicol. 45 , 888-895. http://dx.doi.org/10.1016/j.fct.2006.11.007

Li Y, Zheng J, Xiao H, McClements DJ. 2012. Nanoemulsionbased delivery systems for poorly water-soluble bioactive compounds: influence of formulation parameters on polymethoxyflavone crystallization. Food Hydrocoll. 27, $517-$ 528. https://doi.org/10.1016/j.foodhyd.2011.08.017

Lourith N, Kanlayavattanakul M, Ruktanonchai U, 2016. Formulation and stability of Moringa oleifera oil microemulsion. Soft Matter. 14, 64-71. http://dx.doi.org/10.1080 /1539445X.2016.1141786

McClements DJ. 2012. Nanoemulsions versus microemulsions: terminology, differences, and similarities. Soft Matter. 8, 1719-1729. http://dx.doi.org/10.1039/C2SM06903B

Miura D, Kida Y, Nojima H. 2007. Camellia oil and its distillate fractions effectively inhibit the spontaneous metastasis of mouse melanoma BL6 cells. FEBS Lett. 581, 2541-2548. http://dx.doi.org/10.1016/j.febslet.2007.04.080

Nazarzadeh E, Anthonypillai T, Sajjadi S. 2013. On the growth mechanisms of nanoemulsions. J. Colloid Interface Sci. 397, 154-162. http://dx.doi.org/10.1016/j.jcis.2012.12.018
Odile A-S, L'alloret F, Simonnet J-T. 2001. Nanoemulsion containing nonionic polymers. EP Patent 20010401832

Polychniatou V, Tzia C. 2014. Study of formulation and stability of co-surfactant free water-in-olive oil nano- and submicron emulsions with food grade non-ionic surfactants. $J$. Am. Oil Chem. Soc. 91, 79-88. http://dx.doi.org/10.1007/ s11746-013-2356-3

Quemin E. 2001. Translucent nanoemulsion, production method, and uses thereof in the cosmetic, dermatological and/or ophthalmological fields. EP Patent 20050013409.

Rao J, McClements DJ. 2012. Lemon oil solubilization in mixed surfactant solutions: rationalizing microemulsion \& nanoemulsion formation. Food Hydrocoll. 26, 268-276. http:// dx.doi.org/10.1016/j.foodhyd.2011.06.002

Roohinejad S, Oey I, Wen J, Lee SJ, Everett DW, Burritt DJ. 2015. Formulation of oil-in-water $\beta$-carotene microemulsions: effects of oil type and fatty acid chain length. Food Chem. 174, 270-278. http://dx.doi.org/10.1016/j. foodchem.2014.11.056

Sahari MA, Ataii D, Hamedi M. 2004. Characteristics of tea seed oil in comparison with sunflower and olive oils and its effect as a natural antioxidant. J. Am. Oil Chem. Soc. 81, 585-588. http://dx.doi.org/10.1007/ s1 1746-006-0945-0

Saraf A. 2010. Applications of novel drug delivery system for herbal formulations. Fitoterapia 81, 680-689. http://dx.doi. org/10.1016/j.fitote.2010.05.001

Shafiq S, Shakeel F, Talegaonkar S, Ahmad FJ, Khar RK, Ali M. 2007. Development and bioavailability assessment of ramipril nanoemulsion formulation. Eur. J. Pharm. Biopharm. 66, 227243. http://dx.doi.org/10.1016/j.ejpb.2006.10.014

Solans C, Solé I. 2012. Nano-emulsions: formation by lowenergy methods. Curr. Opin. Colloid Interface Sci. 17, 346-354. http://dx.doi.org/10.1016/j.cocis.2012.07.003

Su MH, Shih MC, Lin K-H. 2014. Chemical composition of seed oils in native Taiwanese Camellia species. Food Chem. 156, 369-373. http://dx.doi.org/10.1016/j. foodchem.2014.02.016

Tang B, Cheng G, Gu J, Xu CH. 2008. Development of solid self-emulsifying drug delivery systems: preparation techniques and dosage forms. Drug Discov. Today 13, 606-612. http://dx.doi.org/10.1016/j.drudis.2008.04.006

Wang L, Dong J, Chen J, Eastoe J, Li X. 2009. Design and optimization of a new self-nanoemulsifying drug delivery system. J. Colloid Interface Sci. 330, 443-448. http://dx.doi. org/10.1016/j.jcis.2008.10.077

Zhao Y, Wang C, Chow AHL, Ren K, Gong T, Zhang Z, Zheng Y. 2010. Self-nanoemulsifying drug delivery system (SNEDSS) for oral delivery of Zedoary essential oil: formulation and bioavailability studies. Int J. Pharm. 383, 170-177. http://dx.doi.org/10.1016/j. ijpharm.2009.08.035 